\title{
Research priorities in land use and land-cover change for the Earth system and integrated assessment modelling $\$$
}

\author{
Kathy Hibbard ${ }^{a * \dagger}$, Anthony Janetos, ${ }^{\mathrm{b}}$ Detlef P. van Vuuren, ${ }^{\mathrm{c}}$ Julia Pongratz, ${ }^{\mathrm{d}}$ Steven K. Rose, ${ }^{\mathrm{e}}$ \\ Richard Betts, ${ }^{\mathrm{f} \ddagger}$ Martin Herold ${ }^{\mathrm{g}}$ and Johannes J. Feddema ${ }^{\mathrm{h}}$ \\ a National Centre for Atmospheric Research, Boulder, CO, USA \\ b Joint Global Change Research Institute, Pacific Northwest National Laboratory/University of Maryland,5825 University Research Court, Suite \\ 3500, College Park, MD 20740, USA \\ c Netherlands Environment Assessment Agency, PO Box 303,3720 BA Bilthoven, The Netherlands \\ ${ }^{\mathrm{d}}$ Carnegie Institution of Washington, Department of Global Ecology, 260 Panama St., Stanford, CA 94305, USA \\ e Electric Power Research Institute \\ ${ }^{\mathrm{f}}$ Head of Climate Impacts, Met Office Hadley Centre, FitzRoy Road, Exeter, EXI 3PB, United Kingdom \\ g Center of Geo-Information, Department of Environmental Science, Wageningen University, Droevendaalsesteeg 3,6708 PB Wageningen, The \\ Netherlands \\ ${ }^{\mathrm{h}}$ Department of Geography, 1475 Jayhawk Blvd, University of Kansas, Lawrence, KS 66049, USA
}

\begin{abstract}
This special issue has highlighted recent and innovative methods and results that integrate observations and modelling analyses of regional to global aspect of biophysical and biogeochemical interactions of land-cover change with the climate system. Both the Earth System and the Integrated Assessment modeling communities recognize the importance of an accurate representation of land use and land-cover change to understand and quantify the interactions and feedbacks with the climate and socio-economic systems, respectively. To date, cooperation between these communities has been limited. Based on common interests, this work discusses research priorities in representing land use and land-cover change for improved collaboration across modelling, observing and measurement communities. Major research topics in land use and land-cover change are those that help us better understand (1) the interaction of land use and land cover with the climate system (e.g. carbon cycle feedbacks), (2) the provision of goods and ecosystem services by terrestrial (natural and anthropogenic) land-cover types (e.g. food production), (3) land use and management decisions and (4) opportunities and limitations for managing climate change (for both mitigation and adaptation strategies). Copyright (C) 2010 Royal Meteorological Society and Crown Copyright.
\end{abstract}

KEY WORDS land use; land cover; Earth system models; integrated assessment models; research priorities

Received 12 January 2009; Revised 9 March 2010; Accepted 14 March 2010

\section{Introduction}

1.1. Land use, land-cover change and global change research

The last 10 years have seen dramatic advances in the ability of scientific communities to simulate important interactions in the Earth system. An important factor

\footnotetext{
* Correspondence to: Kathy Hibbard, National Center for Atmospheric Research, Box 3000, Boulder, CO 80307, USA.

E-mail: kathy.hibbard@pnl.gov

${ }^{\dagger}$ Current address: Pacific Northwest National Laboratory, 902 Battelle Boulevard, Richland, WA 99354, USA.

* The contribution of Richard Betts was written in the course of his employment at the Met Office, UK and is published with the permission of the Controller of HMSO and the Queen's Printer for Scotland.

$\S$ The issues put forward in this work are based on recent interactions of the IAM and ESM communities, i.e. two dedicated workshops of the Integrated Assessment Modeling Consortium (IAMC) and the Analysis, Integration and Modeling of the Earth System (AIMES) core project of the International Geosphere Biosphere Programme (IGBP) held in February and August 2008.
}

in further understanding global change and the role of both human drivers and human interaction of natural systems is demonstrated via land use and land-cover change. Based on this recognition, and also in view of the role of land in providing goods and environmental services, attention to land use and land-cover change is sharply increasing. In this issue, several studies report integrative analyses that incorporate global climate, remote sensing and observations (Lawrence and Chase, 2010; Kvalevåg et al., 2009) while others discuss statistical, weather and/or observations to evaluate regional impacts of land use/land-cover change with climate or biophysical, hydrological processes (Sertel et al., 2009; Costa and Pires, 2009; Blanken et al., 2010; Mishra et al., 2010; Takahashi et al., 2010; Xiou et al., 2009). The strength of these analyses lies in the integrative nature and approach for understanding both the drivers and impacts of land cover and land use with human systems with an emphasis on physical processes. None of these analyses, however, 
(a)
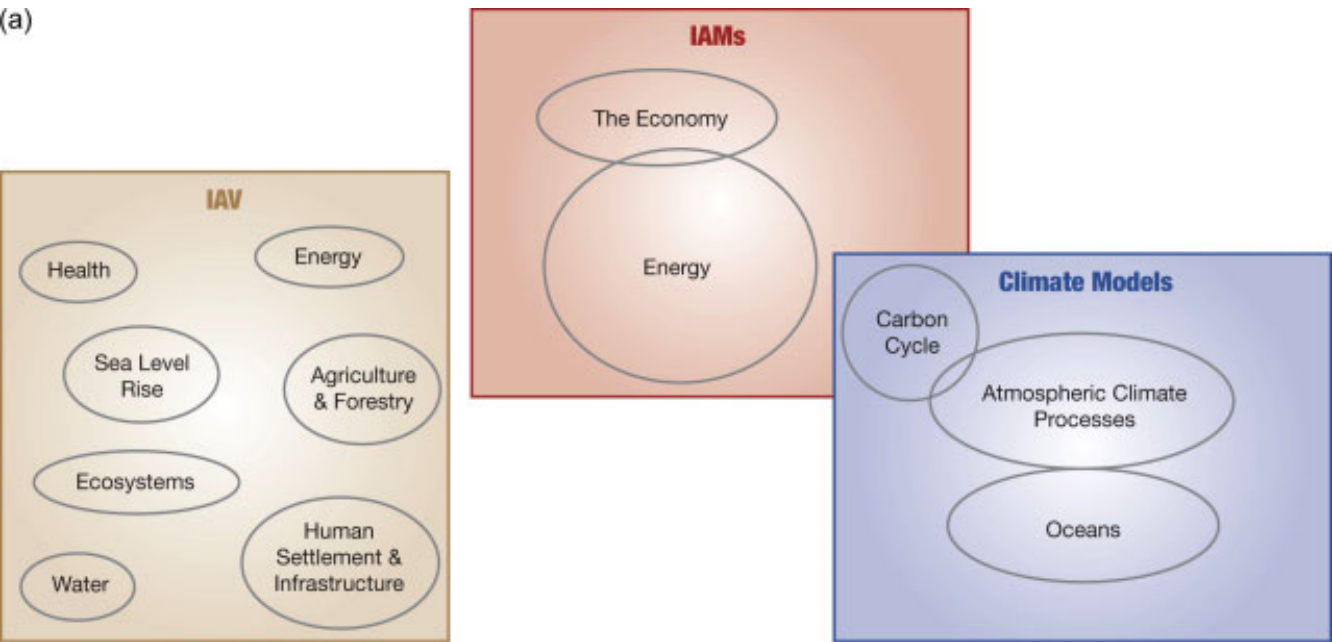

(b)

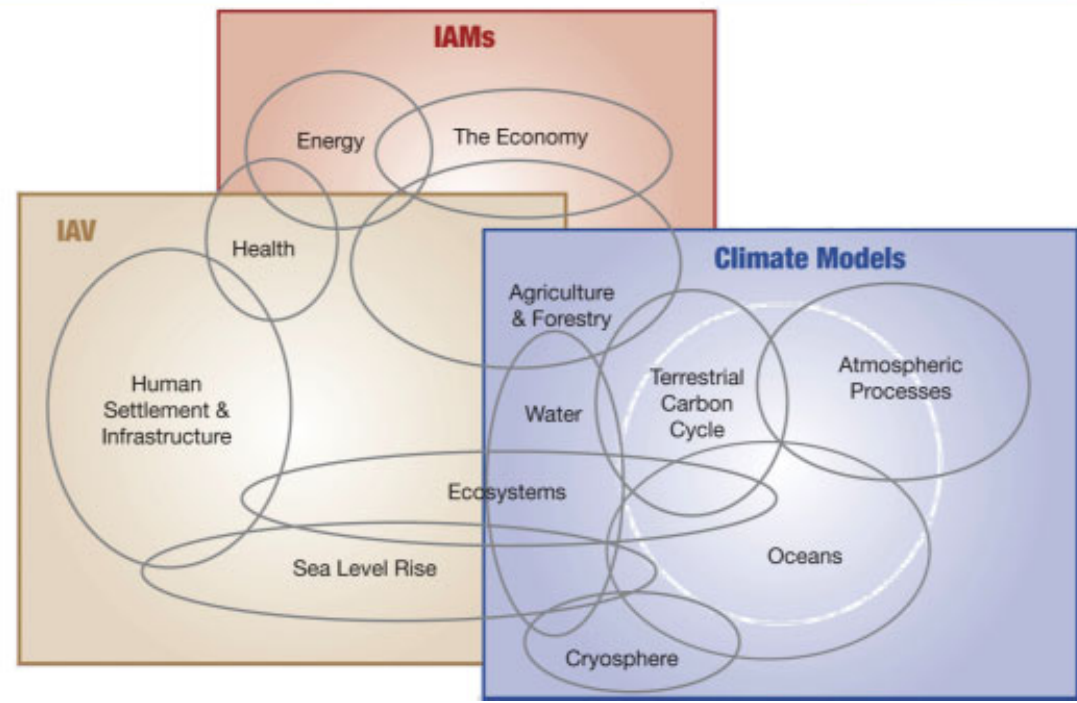

Figure 1. Relative emphasis and sophistication of major modelling components in ESMs and IAMs. (a) Scope of research in the three major climate science communities at the time of the Intergovernmental Panel on Climate Change (IPCC Second Assessment Report (SAR)) and (b) scope of research today. There is a growing overlap in domain and the relative amount of area in the ESM or IAM boxes illustrates the relative level of sophistication/extent of modelling effort allocated to that system in the groups. Note also the growing need for collaboration with the Impacts, Adaptation and Vulnerability (IAV) community. Figure reproduced from Janetos et al. (2009). This figure is available in colour online at wileyonlinelibrary.com/journal/joc

were conducted to address the issues raised from questions that are driven by integrative biogeophysical, socioeconomic and human decision-making perspectives.

The Earth System Modeling (ESM) and the Integrated Assessment Modeling (IAM) communities play an important role in understanding and quantifying Earth system analysis and, specifically, understanding the role of land use and land-cover change. These two groups come from very different perspectives, which result in distinctly different modelling strategies between the groups. Thus, although there is a significant overlap in the systems modelled, there are also components that are unique to each group (Figure 1(a)). The ESM approach is derived from a tradition of using models to analyse the different components and interactions of the Earth's physical system, with a significant emphasis on historical simulations and model evaluation. Although the focus was originally on the physical climate system, more recently the carbon cycle and dynamic vegetation have been added.
By extending its focus, the ESM approach is increasingly adding land-use and land-cover change, hydrology, agriculture and urban systems as integral components of the Earth system. (For purposes of clarification in this work, ESMs represent both the highly computationally expensive coupled atmosphere-ocean general circulation models that incorporate coupled biogeochemistry, atmospheric chemistry and vegetation components as well as the Earth System Models of Intermediate Complexity (EMIC). For further information, see Claussen et al., 2002 or McGuffie and Henderson-Sellers, 2005.) The IAM approach comes largely from a tradition of modelling the interaction of human activities, decision making and the environment. In this work, the focus has been mostly on economic production and consumption, energy systems, greenhouse gas (GHG) emissions and climate change. Land use (timber, agriculture, pasture or grazing) was often also included and increasing attention was focused on improving its representation. The 


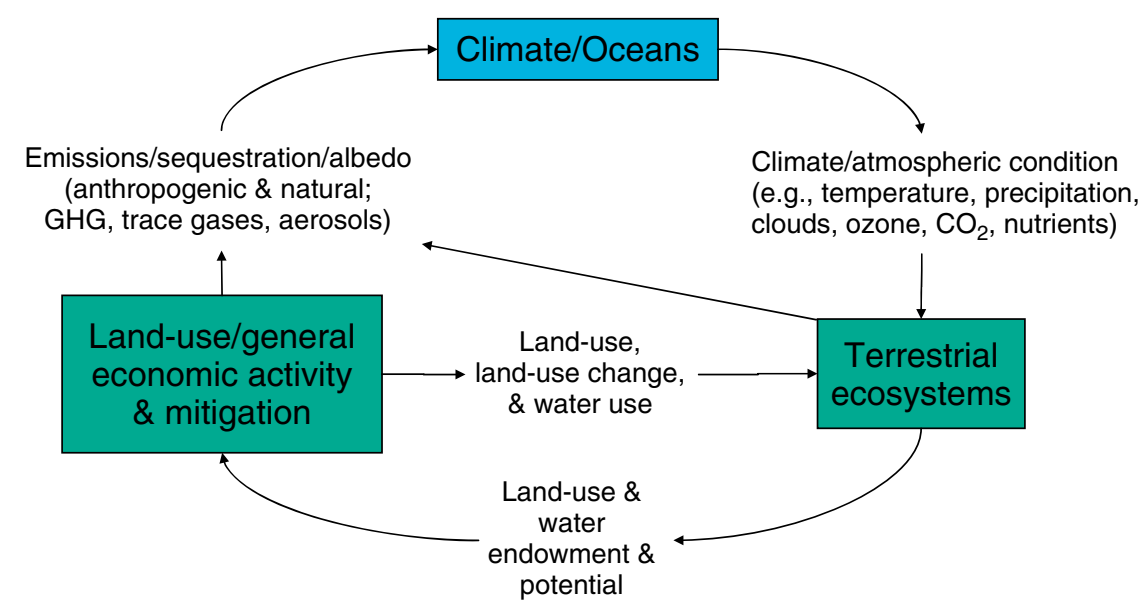

Figure 2. Land in long-run (e.g. centennial) climate modelling (Rose et al., 2008). This figure is available in colour online at wileyonlinelibrary.com/journal/joc

focus in the way ESMs and IAMs represent the systems they study is strongly related to the nature of these systems. In ESMs, more often historical data can be used to equilibrate the model to contemporary time. Given the inherent uncertainty in human systems, in IAMs all kinds of assumptions on future development of factors related to land use such as socio-economic, energy and demographic processes are made. These assumptions are partly based on historical evidence. Often the focus of analysis is not the baseline, but alternative policy scenarios that explore the implications of limited alterations to this set of assumptions (e.g. a climate target). The different focus of the ESM and IAM communities has led to significant differences in emphasis in describing land use and land cover (see also Section 1.3). Although there is a substantial overlap in the systems modelled, there are also components that are unique to each group (Figure 1). Additionally, as both communities acknowledge the need for increased complexity and begin to incorporate additional biogeochemical or socially relevant components in their models, there is an increasing overlap in simulated domain with both the groups including aspects of other modelling strategies (Figure 1(b)).

Improving the description of land use and land-cover change dynamics is the current focus of both groups (Foley et al., 2005; Piao et al., 2008; Rose et al., 2008). This is driven by the role of land system dynamics in global environmental change, and the role of land endowments in providing economic services and that in energy and climate policy and response (Figure 2). In this context, it should be noted that the focus of climate modelling is now shifting from finding an answer to the question 'how will the climate look if we carry-on the way we are going?' to 'what do we need to do to minimize the risk of dangerous climate change, and to adapt to the changes that are now inevitable?' Addressing the latter question relies heavily on behavioural modelling of economic, land use and energy systems, which is the bailiwick of IAMs. In addition, behavioural decisions are defined by the biophysical environment, the strength of the climate and the observational and ecosystem modelling communities.

The two groups have historically worked together in an 'offline' manner, i.e. scenarios that produce radiative GHG and other climate forcings (such as the time evolution of land-use-induced land-cover changes) have been transferred from the IAMs to the climate models without much interaction. More detailed information on the underlying drivers (e.g. land use change) or specific focus on how results of ESMs may impact the underlying drivers of the IAMs (global feedbacks and carbon cycle dynamics) has received very little attention. The observation that interactions between the ESM approach and the IAM approach have been limited to date can also be illustrated by describing the interaction between these communities in the context of the assessments of the Intergovernmental panel on climate change (IPCC). From the onset of IPCC, the climate modelling community has contributed in understanding the physical aspects of climate change, now the focus of Working Group I. The focus of the IAM community has been directed at how land use and emissions may develop and at determining the costs of reducing them, now the focus of Working Group III (Fisher et al., 2007). The two approaches therefore contributed to different working groups. In this context, the interaction between the communities was essentially only a few years away: first for IS92 scenarios (Leggett et al., 1992) and second for the scenarios of the Special Report on Emission Scenarios (SRES) (Nakicenovic et al., 2000). In fact, for the fourth assessment report (AR4) (IPCC 2007), there was no interaction at all between the groups. One may therefore conclude that contact between the integrated assessment and climate modelling communities has been extremely limited. Outside IPCC, however, there have been collaborations in the research domain; but here also one may see this as an exception to a general rule (Sitch et al., 2005; Voldoire et al., 2007). A third engagement occurred recently as the IAM community has provided the climate community with representative concentration and radiative forcing pathways - a group of datasets, including land use 
and land cover, that together describe a broad range of radiative forcing pathways to facilitate a more expansive characterization of potential climate outcomes than ever before (Moss et al., 2008; van Vuuren et al., 2008).

It should be noted that the results of both the climate and IAM simulations have been made broadly available for analysis by other communities as well. The primary groups to utilize modelled results are those that study climate interactions with ecosystems, water resources, biodiversity, agriculture, human settlements and ultimately for understanding the potential for human adaptation to climatic changes, as well as for finer resolution analysis of potential socio-economic and energy transformations associated with long-run climate objectives.

It is important to realize that the ESM and IAM communities do share a common goal, i.e. to understand the continual evolution of the Earth system and all the components that drive that evolution - human decisionmaking and intrinsic natural variability alike. Although these drivers may be of very different origin, both must be understood to improve our understanding of both why the Earth's system behaves as it does now, and what impact future decisions about the human driving forces might hold. There are important interactions between human economic decision making about energy, land use and GHGs, and potential feedbacks in the physical climate system. In this context, these communities should be exploring new research strategies to identify the most important of these interactions, and develop ways to explore them, their consequences and ultimately the consequences of the overall evolution of the Earth system in a more comprehensive and sophisticated way than previously imagined. To some degree, the realization that a major link between human and physical systems is through the carbon cycle is compelling both communities to examine each other's strategies for missing components in their modelled systems.

\subsection{Land use and land-cover change}

A variety of approaches to address land use and landcover change have been considered by both the modelling communities. The modellers of ESM have taken an approach that stems from a combination of basic ecosystem (e.g. carbon cycle) and dynamic global vegetation models (DGVMs), and have begun to incorporate different plant functional types (PFTs) into their model structures. These aspects of ESMs are increasingly being used for understanding the ecosystem and the impacts on hydrology which are modified by ecosystem responses (Betts et al. 2007). Traditionally, information to create an explicit geography of land cover and land surface properties is derived from snapshots of satellite data and often do not acknowledge temporal transitions. However, as land-cover change is also driven by human land use and decision-making processes, ESMs are increasingly adding scenarios of land-use change to their analysis. Historical land cover is typically produced at coarse spatial resolution (e.g. 50-200 $\mathrm{km}^{2}$ ). These reconstructions of land use and land cover are often used to estimate a baseline or reference for current and future carbon stocks and fluxes (e.g. the influence of fire suppression on forest carbon or the influence of past agriculture on soil carbon) and the extent to which land-use change modifies the impacts of climate change such as hydrological changes (Piao et al., 2008).

The IAM community also recognizes the importance of land use as a critical factor in socio-economic decision making, e.g. for food and timber production, valuation of the state of ecosystems and their services, and increasingly, as a response to demand for biofuels in the electricity and transportation sectors. Although many IAMs have focused strongly on energy-economy systems and only included land-use emissions as exogenous factors, this is now changing with the development and implementation of increasingly coupled socio-economic and climate modelling strategies (Rose et al., 2008). How land use is included differs strongly across the IAM community; some IAMs have included land as an additional production factor and relate its use to associated GHG emissions. Such models describe land use at the level of large global regions and would, for instance, differentiate between agricultural land, forested areas and pasture/grazing lands to understand and simulate the economic consequences of changes in supply and demand for these services. The basis of the models is socio-economic and the models rely on census data at national or regional levels of aggregation, with relatively limited specification of landcover characteristics. A small number of models have more detail and, in particular, describe land use and land cover with greater geographical specificity. However, all the models must contend with the fact that economic statistics [such as United Nations Food and Agriculture Organization (FAO) statistics] are national and regional (not gridded or by water sheds); and therefore, land-use decision making must be modelled at this coarser level.

Although a variety of modelling methodologies have benefits in terms of estimating global uncertainties, further collaboration both within and across the two communities can help to advance science, to make use of the best of both worlds (and avoid unnecessary duplication), to enhance integration (also for future climate assessments) and to better understand the role of both human and climate-based uncertainties and their feedbacks. The research issues that have the most potential for productive collaboration between the two modelling communities are identified in this work. In this context, there are three major areas of research priorities where both the ESM and IAM communities may play a role with regard to land-cover and land-use change: deforestation, agriculture and bioenergy. We first highlight ongoing and new model development and how these new model components are being applied through cooperation and evaluation. We finish with a proposed strategy and research priorities for moving forward with an integrative approach for improved understanding of energy, agriculture and forest management. 


\section{Model development strategies: challenges and a brief assessment}

Land cover and land use are not synonymous; however, these words are often (incorrectly) used interchangeably by the IAM and ESM communities. For purposes of clarity, in this work, we consider land cover as a description of the actual vegetation present at the terrestrial surface. Even with this definition, differences in interpretation can arise due to the use of different classification systems to characterize land cover (e.g. biome-type description $v s$ allocation of PFTs). Land use, in contrast, describes the anthropogenic or human use of the land surface, e.g. specific use of maize and commercial timber, and can include land management activities such as irrigation and fertilization that can alter GHG fluxes and climate but not the land cover - cropland and forest, respectively. Land-use change can thus be an important driver for landcover change, but they are not the same. The differences between land use and land cover are also important in the context of data and observation.

All models are driven by data, whether the data are derived from boundary conditions or through parameter estimation, empirical relationships or direct observations. In the end, model estimates, and therefore model error, reflect the information or analyses that are used to establish initial conditions, parameter estimation or internal algorithms. For instance, land-use change emissions are highly uncertain to within a factor of 4, i.e. 500-2700 TgC/y (Denman et al., 2007). This restricts our ability to estimate the strength of global carbon sinks; although fossil fuel emissions and atmospheric $\mathrm{CO}_{2}$ concentrations are well constrained, the large uncertainty in land-use change emissions means that the airborne fraction of total emissions (and hence the fraction of total emissions taken up by land ecosystems and oceans) cannot be constrained so well. Similarly, global land cover as provided by the FAO is often inconsistent with land-cover data and actual practices (e.g. the extent of global plantation forests is uncertain). Modelling groups differ substantially in how lands, such as managed forest, agricultural production, acreage and unmanaged systems, are identified, characterized and paramaterized.

The land-use and land-cover changes associated with mitigation options may impact climate in different ways, and mitigation options currently under consideration at regional and national levels will have major consequences for land use, in particular policies with respect to avoided deforestation/reforestation and bio-energy production. Consistent characterization of mitigation strategies and their implications are largely unknown or unavailable. For instance, reforestation in temperate zones may be used as credit under international climate policy, although some studies have suggested that the associated changes in albedo could at least partly offset the carbon uptake (Betts, 2000; Schaeffer et al., 2006). In contrast, in the tropics, quantification of the climate effects of reforestation (or avoided deforestation) solely in terms of carbon would fail to account for the unchanged or additional cooling effects of altered evapotranspiration (Malhi et al., 2008), so the beneficial effects of tropical forests in mitigating climate warming would be underestimated. Moreover, consideration of only carbon emissions also omits the 'land-use amplifier' effect through which deforestation reduces the carbon sink in addition to acting as an emission source (Gitz and Ciais, 2004). Mitigation options may also have consequences for atmospheric chemistry [e.g. volatile organic compound (VOC) emissions of oil palms, and black carbon emissions from changes in terrestrial fire regimes].

\subsection{Land cover in global climate models}

For clarity, we define two classes of ESMs: (1) coupled Atmosphere-Ocean General Circulation Model (AOGCM) that incorporates endogenous marine and terrestrial carbon cycle dynamics, geographically explicit dynamic vegetation and/or atmospheric chemistry components; and (2) EMIC - a model which compared with (1) takes a simplified or 'reduced' form when one or more components are present. For both the ESM classes, the global carbon cycle is 'closed' (i.e. calculations of the net land-atmosphere and ocean-atmosphere exchanges of, say, $\mathrm{CO}_{2}$ are conservative within the ESM).

In the majority of the global coupled carbon cycleclimate models, several new components are being implemented into their dynamic vegetation and carbon cycle modelling strategies. Some representative processes that are under development and future activities are listed in Table I. At the present time, ESM calculations of the water, energy and carbon fluxes at the land surface and vegetation dynamics are generally limited to regrowth following prescribed disturbance, with limited representation of age-class structure and successional processes (e.g. introduction of invasive species and changes from herbaceous to woody systems).

In the past, climate models have typically assumed fixed land-cover and prescribed GHG concentrations, thereby ignoring both biogeophysical and biogeochemical feedbacks. Land-use change is estimated to account for about $35 \%$ of historical human $\mathrm{CO}_{2}$ emissions (Foley et al., 2005), and accounts for about $20 \%$ of current $\mathrm{CO}_{2}$ emissions (Denman et al., 2007). Initial activities to incorporate land-cover change include first-generation DGVMs (Cox et al., 2000; Cramer et al., 2001) and first-generation Coupled Climate Carbon Cycle Models [C $\mathrm{C}_{4}$ MIP (Friedlingstein et al., 2006)]; both the models focused on natural vegetation and therefore did not consistently treat the effects of land-use change or human-induced land-cover change.

2.2. Land use and land cover in integrated assessment models

Global land-use modelling in most IAMs is generally less developed than other components (e.g. energy system). IAM development is ongoing to more fully internalize land-use decisions associated with both land-use change and changes in the management of land under its existing use. Specifically, new modelling is improving the 
Table I. Near- and longer-term processes under development and consideration for implementation into coupled Atmosphere-Ocean General Circulation Models (AOGCMs).

Near-term $(<5$ years $)$

Terrestrial carbon cycle model (typically without nitrogen or nutrient limitations)

Vegetation dynamics and regrowth following disturbance

Anthropogenic land-use change and corresponding net carbon fluxes

Mechanistic wildfire

Marine biogeochemistry, including simple ocean ecosystem (e.g. nutrient-phytoplankton-zooplankton-detritus (NPZD) models
Longer-term ( $>5$ years)
Nitrogen cycling and limitations

Anthropogenic fire (including ignition and suppression) River biogeochemistry (particularly dissolved organic carbon fluxes from land-to-ocean)

Interactive biogenic fluxes of methane, volatile organic compounds (VOCs) for coupling to atmospheric chemistry Advanced vegetation and successional processes; possibly explicit dispersal mechanisms

Multiple agriculture (crop $\times$ management) PFTs and associated local/regional land-use practices

Transient urban fractional cover

Tropospheric interactions with $\mathrm{O}_{3}$ and vegetation Organic and peatland soils

Wetlands

Delineation of near- and long-term is for general reference and corresponds to broad representation of climate modelling communities from Europe, the United States and Japan. From Meehl and Hibbard (2007).

representation of land-use competition, forestry investment behaviour, changes in forest management, modelling heterogeneous land endowments, internalization of mitigation costs in production and budget decisions, economic rents of land, land-use transitions between specific land types/uses and the supply and access of unmanaged lands (Rose et al., 2008). Recent advances in data and the economic modelling of global land use are facilitating this development (Hertel et al., 2009). IAMs often have several model components that communicate at various levels and frequencies (e.g. energy, climate, land use and land cover). While model components within an IAM are implemented with variable coupling strength (e.g. between socio-economic, energy and climate), it is clear that agriculture, land, land-use change emissions, the economy, energy, $\mathrm{CO}_{2}$ concentrations and climate change are strongly connected. For example, bioenergy has the potential to become a widely used new source that could have major land-use and emissions interactions with and feedbacks to the climate system. IAMs are at various stages of implementing model components that allow competition of bioenergy with food production of land and the impacts on food prices, forests and unmanaged ecosystems, with potential feedback effects from climate change through albedo and emissions.

\subsection{Water, fire and nutrients in the Earth system}

In general, ESMs account for overland routing of water, but do not consider water impoundments. The current IAMs on land use/climate change do not simulate either overland routing or impoundments. However, more dedicated models exist that describe the global water cycle (Vörösmarty et al., 2000; Alcamo et al., 2003). ESMs are introducing more sophisticated hydrology (e.g. water impoundment considerations, thermokarst and freshwater lake systems, ice-stream in river transport (D. Lawrence, pers comm.) into land-cover change modelling, whereas IAMs are beginning to implement basic hydrological processes into their models. This will become more important with increasing pressure and development of urban areas and agriculture in different parts of the world, for both developing and developed countries and to simulate human contributions to changes in runoff, water impoundments (e.g. dams), sediment transport and nutrient flows to ocean systems.

Fire is a key interaction between climate change and land-use change, as changes in fire risk due to climate change may modify the effects of land-use change which often involves fire for forest clearance (Golding and Betts, 2008). Natural or mechanistic fire has been represented in terrestrial ecosystem models since at least the late 1980s (Parton et al., 1987) and is a component of some ESMs. Mechanistic fire is generally parameterized through climate and fuel interactions with probabilities of ignition and have been implemented into the DGVMs (Spessa and Thonicke, 2007; Lenihan et al., 1997). In current IAMs, emissions from biomass burning are not specifically simulated.

Land cover can determine whether the land surface is a source or sink for many chemically active atmospheric species [e.g. VOCs and nitrogen $\left(\mathrm{N}_{2} \mathrm{O}, \mathrm{NO}_{\mathrm{x}}\right)$ ]. Globally, nitrogen has a dual nature in terrestrial ecosystems: there is either not enough nitrogen for agricultural production or there is too much (Galloway and Cowling, 2002; Martinelli and Howarth, 2006). With very few exceptions (Bouwman et al., 2006; Thornton et al., 2009), there is still a great lack of understanding on how to represent correctly the interactions of global biogeochemistry, atmospheric chemistry (beyond carbon) and the coupled human/climate system in both ESMs and IAMs. 


\section{Models, observations and cooperation}

Planned developments in ESM, such as the implementation of new processes (e.g. carbon and/or nitrogen cycle, and dynamic vegetation), and IAM links to the climate system are the first step towards the future development of new scenarios (Moss et al., 2008) and will require strong cooperation between the communities.

\subsection{Feedback of complex carbon cycle/climate change}

Over the last few years, Earth system modelling groups have made considerable effort in including different kinds of feedbacks between the carbon cycle and climate system into their models. Model comparison exercises have shown that these feedbacks can be very significant and that the magnitude, and even the sign of carbon cycle-climate feedbacks, can depend on the land-use scenario and thus may not be easily simplified (Sitch et al., 2008; Friedlingstein et al., 2006). IAMs are often used to explore the impact of different scenarios with and without climate policy (Fisher et al., 2007; van Vuuren et al., 2008b). However, the representation of the carbon cycle and climate system in IAMs is highly simplified (van Vuuren et al., 2010). Therefore, it is important to validate simple representations. The lack of ESM runs with low GHG concentrations and/or by overshoot profiles [an overshoot profile is one where radiative forcing peaks and then declines with time (van Vuuren, 2008b)] makes it difficult to validate the behaviour of the climate system in the simple climate models used in IAMs in these sorts of scenarios. Currently, both communities are working to explore feedbacks and interactions between the coupled carbon and climate systems (Hibbard et al., 2007; Moss et al., 2008; van Vuuren et al., 2008a) under vastly different climate projections. Such insights may lead to recalibration of climate/carbon cycle IAMs, re-evaluation of climate policy strategies and/or re-evaluation of attainability of various climate targets.

\subsection{New activities in land-cover harmonization strategies and remote sensing}

Both the ESM and IAM communities have only recently implemented land-use and land-cover change dynamics. At present, several data sets for historical, present and future land use/land cover have been published (Klein Goldewijk and van Drecht, 2006; Ramankutty et al., 2002; Foley et al., 2005; Ramankutty and Foley, 1999; Pongratz et al., 2008), but there have been few formal multi-model data comparisons to assess the implications for climate system feedbacks. One project, the Land-Use and Climate IDentification of robust impacts (LUCID), is evaluating land-cover interactions with the climate system (Pitman et al., 2009), but it has not yet addressed coupled carbon cycle-climate or socio-economic feedbacks to land-cover or land-use change. Current activities that engage both the ESM and IAM communities are to develop a consistent land-use/land-cover data set for the upcoming IPCC Fifth Assessment Report (AR5).
The development of a single land-cover data system is under development with both communities involved in assessing differences in land-cover characterization and implementation (Hurtt et al., 2009). This first ever collaborative activity will provide a platform for quantifying the importance of differences in land-use input data. Analyses that identify model differences and associated uncertainties by comparing allocation rules of land use on land cover in the ESMs and IAMs will also be performed.

Satellite data, also in conjunction with ground-based observations and historical reconstructions, are valuable tools in characterizing land surface properties as highlighted in this issue (Sertel et al., 2009; Kvalevåg et al., 2009; Fall et al., 2009). With regard to land use/land cover, most spatially explicit data sets are based on remote sensing and national statistics (e.g. HYDE, SAGE, GLCF products and GLC2000). Uncertainties, however, are still significant (Jung et al., 2006) and can result in considerable differences in modelling outcome (Myhre and Myhre, 2003; Jain and Yang, 2005; Jung et al., 2007). Despite these uncertainties, the role of remote sensing for data and model parameterization, calibration and evaluation should be further explored, e.g. concerning key model parameters such as albedo, leaf area index (LAI; see Lawrence and Chase, 2010), fraction of absorbed photosynthetically active radiation (fPAR), yields, potential uses and land-use change transition matrices and the behavioural drivers (e.g. markets, policies and natural events).

The United Nations Framework on Climate Change Convention (UNFCCC) introduced the concept of remotely sensed Essential Climate Variables (ECVs); originally identified for the implementation plan developed by the Global Climate Observing System (GCOS), with 13 ECVs targeted to address terrestrial observations (Table II). In particular, the Global Terrestrial Observing System (GTOS) is developing possible mechanisms for a terrestrial framework and assisting the consistent and continuous observation of the 13 terrestrial ECVs, including the assessment of the status of available standards (Sessa and Dolman, 2008). To date, some activities have used different existing global observations and derived specific global products, for instance, SYNMAP (Jung et al., 2006), which is a synthesis of existing global land-cover maps to provide a targeted and improved land-cover map for carbon cycle modelling, and a global urban mapping synthesis (Potere and Schneider, 2008).

It has long been recognized that observations and, in particular, remotely-sensed products are often crosscalibrated with various global data sets (e.g. GLC2000 as reference for comparison with UMD, IGCP, MODIS and SYNMAP) as well as spatial heterogeneity of land-cover classes (Herold et al., 2008a). These and other analyses have initiated the development of strategies for a landcover classification system (LCCS), providing a common terminology where various data sets can be compared and evaluated to improve their synergy, usability and flexibility. In addition, new global land-cover products with more detailed spatial resolution (e.g. GLOBCOVER 
Table II. Global terrestrial essential climate variables (ECVs) and examples of existing and evolving observing systems.

Terrestrial ECV

River discharge

Water use

Groundwater

Lake and reservoir levels and volumes

Snow cover

Glaciers and ice caps

Permafrost

Albedo and reflectance anisotropy

Land cover

Fraction of absorbed photosynthetically active

radiation (FAPAR)

Leaf area index

Biomass

Fire disturbance

Soil moisture
Observing system

\author{
In situ \\ In situ networks, regional remote sensing activities \\ In situ \\ In situ networks, regional remote sensing activities \\ GLOBSNOW \\ GLOBGLACIER \\ Regional activities (i.e. circum-arctic) \\ GLOBALBEDO \\ GLOBCOVER, MODIS land cover \\ GLOBCARBON, MODIS and Seawifs products
}

GLOBCARBON, MODIS products

Regional activities, e.g. Siberia

Several global products from AATSR or MODIS

SMOS satellite mission

Many global ECV monitoring activities build upon satellite data as primary observation source. The European Space Agency (ESA) has started to arrange their global observing commitments according to ECV requirements and are described first, followed by others (e.g. US and Japan).

2005 with $300 \times 300 \mathrm{~m}$ or MODIS with $500 \times 500 \mathrm{~m})$ and thematic detail in the LCCS have recently become available for global and regional applications requiring up-to-date and flexible land-cover mapping data. As these new products are developed and made available to the scientific community, an operational accuracy assessment system for the identification of problems in characterizing heterogeneous areas is in evolution for the quantification and treatment of error. It is anticipated that these new and ongoing products will be available for integration into ESMs and IAMs. A key application will be for the detection and attribution of historical climate change; previous detection and attribution studies have been unable to include land-cover change credibly in their range of potential drivers (Hegerl et al., 2007), but improved models and more complete data sets now allow this process to be included in such studies (Lawrence and Chase, 2010; Fall et al., 2009; Sertel et al., 2009).

Driven by several international policy processes (i.e. UNFCCC post-2012 climate negotiations), substantial investments are currently being made to improve terrestrial carbon monitoring in many developing countries [i.e. emissions from deforestation (Herold and Johns, 2007)]. These efforts use both historical remote sensing data, at fine scales (i.e. Landsat-type data), and in situ data to quantify changes in forest area and changes in carbon stocks, respectively. The 2010 Forest Resources Assessment of FAO will include a global remote sensing survey providing a systematic sample-based assessment of historical forest and land changes on regional and global levels. In conjunction with change observations using coarser-resolution satellite data (i.e. long-term trends in Normailized Difference Vegetation Index time series, fire observations, night-time lights, hot-spot detection, etc.), a new level of data products and information on land dynamics will soon become available for different time periods since about 1990 (Herold et al., 2008b).

\section{Moving forward with three integrative processes: deforestation, agriculture and bioenergy}

Three global land-use phenomena (deforestation, agriculture and bioenergy) are very topical for international policy making, and are being studied by the ESM and IAM communities. We argue that these three phenomena are main areas where further collaboration between these communities, together with observing (e.g. remote sensing) communities, could advance current scientific understanding. The phenomena are clearly driven by socio-economic drivers and different policies, but understanding them also requires a comprehensive examination of physical, biogeochemical and ecosystem processes. These directly relate to the issues we have raised in the previous sections (e.g. through hydrology, disturbance, biogeochemistry and socio-economic). Bridges between the observation, measurement, modelling and decisionmaking communities will be necessary to resolve integrative land-use and decision-making questions.

\subsection{Land use and deforestation}

Deforestation and its associated processes are important with regard to the carbon cycle and feedbacks to the climate system. Empirical evidence of the rates of change of deforestation has been available for the past 25 years, and future progress is anticipated with new observing systems, and measuring and modelling tools. Deforestation comprises the aspects of both human decision making, as it is clearly a consequence of both economic and non-economic decision making, and biogeochemical processes. In addition, the uncertainties associated with the net flux of carbon are of the same order as that for the size of the net flux (e.g. around $20 \%$ of the gross flux, or total flux). It is also important to understand the recent past, because both the human and the biogeochemical processes that contribute to the rates and magnitudes of deforestation are very likely to continue 
to be important in the future. Finally, deforestation is a major element in climate policy discussions. The skill of IAMs to reproduce land-clearing phenomena that resemble the timing and magnitude as recorded by observing systems has not been tested. The same holds for the carbon cycle consequences of these changes, in both IAMs and ESMs. Consequently, an important research priority is to improve the representation of recent past (e.g. 20+ years) to contemporary deforestation in models, including the relationship between deforestation and climate policy choices. Representation of rates of deforestation in ESMs is largely dependent on information from historical sources, the integrated assessment and remote sensing communities. We strongly recommend coupled analyses with both modelling and observing communities to (a) better quantify socio-economic and political processes that drive rates of deforestation, (b) reduce uncertainties in sources and sinks of GHGs from deforestation processes and (c) evaluate the integrated impacts of deforestation accounting for both biogeophysical and biogeochemical feedbacks.

\subsection{Land use and agriculture}

Analyses with IAMs have explored range-finding exercises on agricultural productivity through analyses of crop productivity for food versus fuel and whether or not carbon is valued (Strengers et al., 2004; Wise et al., 2009). Assumptions on agricultural productivity critically determine land use in the coming century. They also determine the potential for bioenergy (de Vries et al., 2007). Moreover, results suggest that when carbon is valued, crop prices raise significantly, even in the absence of crops grown specifically for bioenergy production. Conversely, substantially more bioenergy production occurs when terrestrial carbon is not valued. Both socio-economic and cultural decision-making processes govern agricultural production from individual landowner to landscape and regional scales. However, there are significant uncertainties in fundamental economic and land productivity parameters that can meaningfully affect results. For global models with underlying objectives to understand and quantify climate system dynamics, the practicality of specifying crop types and regionality must be carefully considered. Appropriate scales for decision making to specific changes in crop management strategies as a consequence of changes in climate, changes in demand for food and changes in the relative cost of land inputs to production in the context of a dynamic policy environment provide a backdrop of the complexity of agricultural economic and policy landscapes.

\subsection{Land use and bioenergy production}

Within the last several years, bioenergy production has generated substantial political and economic interest. Most IAM groups have initiated simulation studies of bioenergy production and there have been some comparisons of results (Rose et al., 2008). Although ESMs can specify a vegetation proxy (e.g. grass and crop) to simulate biofuels, it is not clear how to incorporate bioenergy production into an ESM experimental design. Several approaches can be considered: whether to simply and artificially increase agricultural productivity, or whether processes and energy fluxes associated with increased fertilization, irrigation and crop rotations require a new biogeophysical modelling strategy, including the implementation of age or cohort structure (Moorcroft et al., 2001).

\section{Discussion}

Within the topics of deforestation, agricultural production and bioenergy, interaction with the impacts, adaptation and vulnerability communities is clearly important. A model-evaluation exercise that incorporates a 'soft coupling' (e.g. offline) between IAMs and ESMs of land would provide a 'proof of concept' for short-term analyses that could be linked with impacts and/or adaptation studies. Clearly, both ESMs and IAMs will require confrontation with data. Benchmarking exercises that rigorously evaluate model performance against observations and measurements is needed. In addition, guidelines for interpreting land-use and land-cover classes (e.g. pasture lands, savanna and grazing lands) are needed. For instance, land allocations for grazing lands can be quite different, or how a global model classifies whether a land allocation is to be grazed can be distinctly different between mesic or arid/semi-arid ecosystems. It is also important to note that it is simply not enough to reproduce observations, as calibration for one region may result in distorted results in another. In this context, the programmes under development for observing ECVs as outlined by the GTOS (2007) consider this broad set of needs for both land-cover and land-use monitoring in an integrated and consistent manner. Process understanding, both from the socio-economic and the natural science's view point, will be important considerations. We also suggest that many applications view IPCC as a default framework to promote collaboration, but there are others, including but not limited to ecosystem services, Earth system science, sustainable development, the IAMC and various government programmes.

\section{Acknowledgements}

The authors wish to thank the Integrated Assessment Modeling Consortium (IAMC) and the Analysis, Integration and Modeling of the Earth System (AIMES) core project of the International GeosphereBiosphere Programme (IGBP), and the World Climate Research Programmes' Working Group on Coupled Models (WCRP/WGCM) for their support in organizing the workshops that contributed to this work. Specifically, the work was developed from the joint AIMES-IAMC meeting in preparation of scenario analysis for climate change assessment held in Washington DC, 6-8 February 2008, and the IAMC-EMF meeting held in Snowmass, 2008. The authors are grateful for the insights of the other workshop participants during these workshops and for reviews from three anonymous referees. 


\section{References}

Alcamo J, Döll P, Henrichs T, Kaspar F, Lehner B, Rösch T, Siebert S. 2003. Development and testing of the WaterGAP 2 global model of water use and availability. Hydrological Sciences Journal 48(3): 317-338.

Betts RA. 2000. Offset of the potential carbon sink from borea forestation by decreases in surface albedo. Nature 408: 187-190.

Betts RA, Boucher O, Collins M, Cox PM, Falloon PD, Gedney N, Hemming D, Huntingford C, Jones CD, Sexton DMH, Webb MJ 2007. Projected increase in continental runoff due to plant responses to increasing carbon dioxide. Nature 448: 1037-1041.

Bouwman L, Kram T, Klein-Goldewijk K. 2006. Integrated modeling of global environmental change. An overview of IMAGE 2.4. Netherlands Environmental Assessment Agency: Bilthoven.

Claussen M, Mysak LA, Weaver AJ, Crucifix M, Fichefet T, Loutre MF, Weber SL, Alcamo J, Alexeev VA, Berger A, Calov R, Ganopolski A, Goosse H, Lohman G, Lunkeit F, Mokhov II, Petoukhov V, Stone P, Wang Zh. 2002. Earth system models of intermediate complexity: closing the gap in the spectrum of climate system models. Climate Dynamics 18(7): 579-586, DOI: 10.1007/s00382-001-0200-1.

Costa MH, Pires GF. 2009. Effects of Amazon and Central Brazil deforestation scenarios on the duration of the dry season in the arc of deforestation. Int. J. Climatol. 30: 1970-1979, DOI: 10.1002/joc. 2048

Cox PM, Betts RA, Jones CD, Spall SA, Totterdell IJ. 2000. Acceleration of global warming due to carbon-cycle feedbacks in a coupled climate model. Nature 408: 184-187.

Cramer W, Bondeau A, Woodward FI, Prentice IC, Betts R, Brovkin V, Cox PM, Fischer V, Foley JA, Friend AD, Kucharik C, Lomas MR, Ramankutty N, Sitch S, Smith B, White A, Young-Molling C. 2001. Global response of terrestrial ecosystem structure and function to $\mathrm{CO} 2$ and climate change: results from six dynamic global vegetation models. Global Change Biology 7: 357-373.

Denman KL, Brasseur G, Chidthaisong A, Ciais P, Cox PM, Dickinson RE, Hauglustaine D, Heinze C, Holland E, Jacob D, Lohmann U, Ramachandran S, da Silva Dias PL, Wofsy SC, Zhang X. 2007. Couplings between changes in the climate system and biogeochemistry. In Climate Change 2007: The Physical Science Basis. Contribution of Working Group I to the Fourth Assessmen Report of the Intergovernmental Panel on Climate Change. Solomon S,Qin D, Manningetal M (eds). Cambridge University Press: Cambridge.

Fall S, Niyogi D, Gluhovsky A, Pielke RA Sr, Kalnay E, Rochon G 2009. Impacts of land use land cover on temperature trends over the continental United States: assessment using the North American Regional Reanalysis. Int. J. Climatol. 30: 1980-1993, DOI: $10.1002 /$ joc. 1996 .

Fisher B, Nakicenovic N, Alfsen K, Corfee Morlot J, De la Chesnaye F, Hourcade J-C, Jiang K, Kainuma M, La Rovere E, Matysek A, Rana A, Riahi K, Richels R, Rose S, Van Vuuren DP, Warren R. 2007. Issues related to mitigation in the long-term context. In Climate Change 2007 - Mitigation. Metz B, Davidson O, Bosch P, Dave R, Meyer L (eds). Cambridge University Press: Cambridge.

Foley JA, DeFries R, Asner GP, Barford C, Bonan G, Carpenter SR, Stuart Chapin F, Coe MT, Daily GC, Gibbs HK, Helkowski JH, Holloway T, Howard EA, Kucharik CJ, Monfreda C, Patz JA, Prentice C, Ramankutty N, Snyder PK. 2005. Global consequences of land use. Science 309(5734): 570-574.

Friedlingstein P, Cox P, Betts R, Bopp I, Von bloh W, Brovkin V, Cadule P, Doney S, Eby M, Fung I, Bala G, John J, Jones C Joos F, Kato T, Kawamiya M, Knorr W, Lindsay K, Matthews HD, Raddatz T, Rayner P, Reick C, Roeckner E, Schnitzler KG Schnur R, Strassmann K, Weaver AJ, Yoshikawa C, Zeng N. 2006. Climate - carbon cycle feedback analysis: results from the C4MIP model intercomparison. Journal of Climate 19: 3337-3353.

Galloway JN, Cowling EB. 2002. Nitrogen and the world. Ambio 31(2): 64-71.

Gitz V, Ciais P. 2004. Future expansion of agriculture and pasture acts to amplify atmospheric $\mathrm{CO} 2$ in response to fossil fuel and land-use change emissions. Climatic Change 67: 161-184.

Golding N, Betts R. 2008. Fire risk in Amazonia due to climate change in the HadCM3 climate model: Potential interactions with deforestation. Global Biogeochem. Cycles 22: GB4007, DOI: 10.1029/2007 GB003166.

Global Terestrial Observing System (GTOS). 2007. Assessing the status of the development of standards for the Essential Climate Variables in the terrestrial domain. Progress Report to the 26th Meeting of the Subsidiary Body for Scientific and Technological Advice (SBSTA). Bonn, Germany. 24 pp. http://gosic.org/ios/MATRICES/ECV/ECVmatrix-Reference-Documents.htm.

Hegerl GC, Zwiers FW, Braconnot P, Gillett NP, Luo Y, Marengo Orsini JA, Nicholls N, Penner JE, Stott PA. 2007. Understanding and attributing climate change. In Climate Change 2007: The Physical Science Basis. Contribution of Working Group I to the Fourth Assessment Report of the Intergovernmental Panel on Climate Change. Solomon S, Qin D, Manning M, Chen Z, Marquis M, Averyt KB, Tignor M, Miller HL (eds.). Cambridge University Press: Cambridge, United Kingdom and New York

Herold M, Johns T. 2007. Linking requirements with capabilities for deforestation monitoring in the context of the UNFCCC-REDD process. Environmental Research Letters 2: 7. http:/erl.iop.org.

Herold M, Woodcock C, Mayaux P, Baccini A, Schmullius CC. 2008a. Some challenges in global land cover mapping: an assessment of agreement and accuracy in existing $1 \mathrm{~km}$ datasets. Remote Sensing of Environment 112: 2538-2556.

Herold M, Woodcock CE, Loveland TR, Townshend J, Brady M, Schmullius C. 2008b. Land cover observations as part of a global earth observation system of systems (GEOSS): progress, activities, and prospects. IEEE Systems 2(3): 414-423.

Hertel T, Rose S, Tol R (eds.) 2009. Economic Analysis of Land Use in Global Climate Change Policy. Routledge Publishing: 343.

Hibbard KA, Meehl G, Cox P, Friedlingstein P. 2007. A strategy for climate change stabilization experiments. EOS 88(20): 217-221.

Hurtt GC, Chini LP, Frolking S, Betts R, Feddema J, Fischer G, Goldewijk KK, Hibbard K, Janetos A, Jones C, Kinderman G, Kinoshita T, Riahi K, Shevliakova E, Smith S, Stehfest E, Thomson A, Thornton P, vanVuuren D, Wang YP. 2009. Harmonization of global land-use scenarios for the period 1500-2100 for IPCCAR5. iLEAPS Newsletter 7: 6-8.

IPCC. 2007. Climate Change 2007 - Synthesis Report. Contribution of Working Groups I, II and III to the Fourth Assessment Report of the Interngovernmental Panel on Climate Change. Cambridge University Press: Cambrige.

Jain A, Yang X. 2005. Modeling the effects of two different land cover change data sets on the carbon stocks of plants and soils in concert with $\mathrm{CO} 2$ and climate change. Global Biogeochem. Cycles 19: GB2015, DOI: $10.1029 / 2004$ GB002349.

Janetos AC, Clarke L, Collins B, Ebi K, Edmonds J, Foster I, Jacoby J, Judd K, Leung R, Newell R, Ojima D, Pugh G, Sanstad A, Schultz P, Stevens R, Weyant J, Wilbanks T. 2009. Science challenges and future directions: climate change integrated assessment research. Report PNNL-18417 from the US Department of Energy, Office of Science: 80 pp. http://www.sc.doe.gov/ober/ BER_workshops.html (accessed 2009).

Jung M, Henkel K, Herold M, Churkina G. 2006. Exploiting synergies of global land cover products for carbon cycle modeling. Remote Sensing of Environment 101: 534-553.

Jung M, Vetter M, Herold M, Churkina G, Viovy N, Zaehle S, Bondeau A, Reichstein M, Chen Y, Trusilova K, Feser F, Heimann M. 2007. Uncertainties of modeling GPP over Europe: A systematic study on the effects of using different drivers and carbon cycle models. Global Biogeochemical Cycles 21: GB4021, DOI: 10.1029/2006 GB002915.

Kvalevåg MM, Myhre G, Bonan G, Levis S. 2009. Anthropogenic land cover changes in a GCM with surface albedo changes based on MODIS data. Int. J. Climatol. 30: 2105-2117, DOI: 10.1002/joc. 2012

Klein Goldewijk K, van Drecht G. 2006. HYDE 3: Current and historical population and land cover. In Integrated modeling of global environmental change. An overview of IMAGE 2.4. Bouwman AF, Kram T, Klein Goldewijk K (eds.). Netherlands Environmental Assessment Agency (MNP): Bilthoven, The Netherlands.

Lawrence PJ, Chase TN. 2010. Investigating the climate impacts of global land cover change in the community climate system model. Int. J. Climatol. 30: 2066-2087, DOI: 10.1002/joc.2061

Leggett J, Pepper W, Swart R. 1992. Emissions scenarios for the IPCC: an update. In Climate Change 1992, Houghton JT, Callender BA, Varney SK (eds). Cambridge University Press: Cambridge.

Lenihan JM, Daly C, Bachelet D, Neilson RP. 1997. Simulating broadscale fire severity in a Dynamic Global Vegetation Model. Northwest Science 72: $91-103$.

Malhi Y, Roberts JT, Betts RA, Killeen TJ, Li WH, Nobre CA, 2008. Climate change, deforestation, and the fate of the Amazon. Science 319: $169-172$. 
Martinelli L, Howarth RW. 2006. Nitrogen cycling in the Americas: natural and anthropogenic influences and controls. Biogeochemistry 79: $1-2$.

McGuffie K, Henderson-Sellers A (eds). 2005. A Climate Modelling Primer, 3rd edn. John Wiley and Sons: England 60p.

Meehl GA, Hibbard K, and meeting participants. 2007. A strategy for climate change stabilization experiments with AOGCMs and ESMs. Report of the Aspen Global Change Institute 2006 Session: Earth System Models: The Next Generation. WCRP Report No. 3/2007, ICPO Publication No. 112, IGBP Report No. 5730 July-5 August 2006, Aspen, Colorado. 37 pp. http:// www.aimes.ucar.edu/activities/WCRP/Aspen_WhitePaper_final.pdf (accessed 2007).

Mishra V, Cherkauer KA, Niyogi D, Lei M, Pijanowski BC, Ray DK, Bowling LC, Yang G. 2010. A regional scale assessment of land use/land cover and climatic changes on water and energy cycle in the Upper Midwest United States. Int. J. Climatol. 30: 2025-2044, DOI: $10.1002 /$ joc.2095

Moorcroft PR, Hurtt GC, Pacala SW. 2001. A method for scaling vegetation dynamics: the ecosystem demography model (ED). Ecological Monographs 71(4): 557-586.

Moss R, Babiker M, Brinkman S, Calvo E, Carter T, Edmonds J, Elgizouli I, Emori S, Erda L, Hibbard K, Jones R, Kainuma M, Kelleher J, Lamarque JF, Manning M, Matthews B, Meehl G, Meyer L, Mitchell J, Nakicenovic N, O’Neill B, Pichs T, Riahi K, Rose S, Runci P, Stouffer R, van Vuuren D, Weyant J, Wilbanks T, van Ypersele JP, Zurek M. 2008. Towards New Scenarios for Analysis of Emissions, Climate Change, Impacts, and Response Strategies. Intergovernmental Panel on Climate Change: Geneva.

Myhre G, Myhre A. 2003. Uncertainties in radiative forcing due to surface albedo changes caused by land-use changes. Journal of Climate 16: 1511-1524.

Nakicenovic N, Alcamo J, Davis G, De Vries B, Fenhamm J, Gaffin S, Gregory K, Gruebler A, Jung TY, Kram T, Lebre La Rovere E, Michaelis L, Mori S, Morita T, Pepper W, Pitcher H, Price L, Riahi K, Roehrl A, Rogner HH, Sankovski A, Schlesinger M, Shukla P, Smith S, Swart R, Van Rooyen S, Victor N, Zhou D. 2000. IPCC Special Report on Emissions Scenarios. Cambridge University Press: Cambridge.

Parton WJ, Schimel DS, Cole CV, Ojima DS. 1987. Analysis of factors controlling soil organic matter levels in great plains grasslands. Soil Science Society of America Journal 51: 1173-1179.

Petchprayoon P, Blanken PD, Ekkawatpanit C, Hussein K. 2010. Hydrological impacts of land use/land cover change in a large river basin in central-northern Thailand. Int. J. Climatol. 30: 1917-1930, DOI: $10.1002 /$ joc. 2131

Piao S, Friedlingstein P, Ciais PPh, de Noblet-Ducoudré N, Labat D, Zaehle S. 2008. Changes in climate and land use have a larger direct impact than rising $\mathrm{CO}_{2}$ on global river runoff trends. Proceedings of the National Academy of Sciences of the United States of America 104(39): 15242-15247.

Pitman AJ, de Noblet-Ducoudré N, Cruz FT, Davin EL, Bonan GB, Brovkin V, Claussen M, Delire C, Ganzeveld L, Gayler V, van den Hurk BJJM, Lawrence PJ, van der Molen MK, Müller C, Reick CH, Seneviratne SI, Strengers BJ, Voldoire A. 2009. Uncertainties in climate responses to past land cover change: First results from the LUCID intercomparison study. Geophysical Research Letters 36: L14814, DOI: 10.1029/2009GL039076.

Pongratz J, Reick C, Raddatz T, Claussen M. 2008. A reconstruction of global agricultural areas and land cover for the last millennium. Global Biogeochemical Cycles 22: GB3018, DOI: 10.1029/2007 GB003153.

Potere D, Schneider A. 2008. Comparison of global urban maps. In Global Mapping of Human Settlement: Experiences, Data Sets, and Prospects, Gamba P, Herold M (eds). Taylor and Francis: New York.

Ramankutty N, Foley J. 1999. Estimating historical changes in global land cover: croplands from 1700 to 1992. Global Biogeochemical Cycles 13: 997-1028.

Ramankutty N, Foley JA, Norman J, McSweeney K. 2002. The global distribution of cultivable lands: current patterns and sensitivity to possible climate change. Global Ecology and Biogeography 11(5): 377-392.

Rose S, Ahammad H, Eickhout B, Fisher B, Kurosawa A, Rao S, Riahi K, van Vuuren D. 2008. Land in Climate Stabilization
Modeling: initial observations. EMF Report Number 21, Energy Modeling Forum. Stanford University, Stanford, USA.

Schaeffer M, Eickhout B, Hoogwijk M, Strengers B, Van Vuuren DP, Leemans R, Opsteegh T. 2006. $\mathrm{CO}_{2}$ and albedo climate impacts of extratropical carbon and biomass plantations. Global Biogeochemical Cycles 20(2): GB2020.

Sertel E, Robock A, Ormeci C. 2009. Impacts of land cover data quality on regional climate simulations. Int. J. Climatol. 30: 1942-1953, DOI:10.1002/joc.2036

Sessa R, Dolman H, eds. 2008. Terrestrial Essential Climate Variables for Climate Change Assessment, Mitigation and Adaptation. Report of the Global Terrestrial Observing System GTOS:52. Food and Agricultural Organization of the United Nations, Rome.

Sitch S, Brovkin V, Von Bloh W, Van Vuuren DP, Eickhout B, Ganopolski A. 2005. Impacts of future land cover changes on atmospheric $\mathrm{CO}_{2}$ and climate. Global Biogeochemical Cycles 19(2): GB2013, DOI:10.1029/2004GB002311.

Sitch S, Huntingford C, Gedney N, Levy PE, Lomas M, Piao SL, Betts R, Ciais P, Cox P, Friedlingstein P, Jones CD, Prentice IC, Woodward FI. 2008. Evaluation of the terrestrial carbon cycle, future plant geography and climate-carbon cycle feedbacks using 5 Dynamic Global Vegetation Models (DGVMs). Global Change Biology 14: 2015-2039.

Spessa A, Thonicke K. 2007. LPJ+SPITFIRE and the Importance of Fire in the Earth system, ICESM Abstracts 1: ICESM2007-A-00170. Strengers B, Leemans R, Eickhout B, De Vries B, Bouwman L. 2004. The land-use projections and resulting emissions in the IPCC SRES scenarios as simulated by the IMAGE 2.2 model. GeoJournal 61(4): $381-393$.

Takahashi HG, Yoshikane T, Hara M, Takata K, Yasunari T. 2010. High-resolution modelling of the potential impact of land-surface conditions on regional climate over Indochina associated with the diurnal precipitation cycle. Int. J. Climatol. 30: 2004-2020, DOI: 10.1002/joc. 2119 .

Thornton PE, Doney SC, Lindsay K, Moore JK, Mahowald N, Randerson JT, Fung I, Lamarque J-F, Feddema JJ, Lee Y-H. 2009. Carbon-nitrogen interactions regulate climate-carbon cycle feedbacks: results from an atmosphere-ocean general circulation model. Biogeosciences 6(10): 2099-2120.

Van Vuuren DP, Feddema J, Hibbard K, Hurtt G, Lamarque JF, Riahi K, Rose S, Smith S. 2008a. Draft Work Plan for Data Exchange between the Integrated Assessment and Climate Modeling community in Support of the Preparatory Phase of Scenario Analysis for Climate Change Assessment (Representative Concentration Pathways). http://www.aimes.ucar.edu (accessed 2008).

van Vuuren DP, Meinshausen M, Plattner G-K, Joos F, Strassmann KM, Smith SJ, Wigley TML, Raper SCB, Riahi K, de la Chesnaye F, den Elzen MGJ, Fujino J, Jiang K, Nakicenovic N, Paltsev S, Reilly JM. 2008b. Temperature increase of 21st century mitigation scenarios. Proceedings of the National Academy of Sciences 105(40): 15258-15262.

van Vuuren DP, Lowe J, Stehfest E, Gohar L, Hof AF, Hope C, Warren R, Meinshausen M, Plattner GK. 2010. How well do integrated assessment models simulate climate change? Climatic Change. DOI: 10.1007/s10584-009-9764-2.

Voldoire A, Eickhout B, Schaeffer M, Royer JF, Chauvin F. 2007. Climate simulation of the twenty-first century with interactive landuse changes. Climate Dynamics 29(2-3): 177-193.

Vörösmarty CJ, Green P, Salisbury J, Lammers R. 2000. Global water resources: vulnerability from climate change and population growth. Science 289: 284-288.

de Vries BJM, van Vuuren DP, Hoogwijk MM. 2007. Renewable energy sources: their global potential for the first-half of the $21 \mathrm{st}$ century at a global level: an integrated approach. Energy Policy 35(4): 2590-2610.

Wise M, Calvin K, Thomson A, Clarke L, Bond-Lamberty B, Sands R, Smith SJ, Janetos A, Edmonds J. 2009. Implications of limiting $\mathrm{CO}_{2}$ concentrations for land use and energy. Science 324: 1183-1186.

Xiao C, Yu R, Fu Y. 2009. Precipitation characteristics in the Three Gorges dam vicinity. Int. J. Climatol. 30: 2021-2024, DOI: 10.1002/joc. 1963 